\title{
An Outline of a Phenomenology of Solidarity: Beyond the Bridge Problem
}

\author{
WITOLD PŁOTKA
}

Institute of Philosophy, Cardinal Stefan Wyszynski University in Warsaw, 1/3 Wóycickiego Street, Building 23, PL-01-938 Warsaw, Poland Email:w.plotka@uksw.edu.pl

\begin{abstract}
The aim of the article is to present main elements, problems and preliminary solutions connected to a phenomenology of solidarity. The article is divided into three parts. In the first part, the author defines the bridge problem as an attempt to bind subjective and intersubjective levels of constitution, and he shows that neither Ingarden nor Tischner can solve the problem. In the second part, the author presents the act of solidarization as a complex act which binds cognitive, volitional and affective dimensions. Finally, the author sketches an alternative approach to a phenomenology of solidarity that leads beyond the bridge problem, namely, Husserl's theory of constitution of groups in joint action.
\end{abstract}

Keywords: intersubjectivity, solidarization, joint actions, constitution of groups, Ingarden, Tischner, Husserl

\section{INTRODUCTION}

The main aim of this study is an attempt in a phenomenology of solidarity. Solidarity or solidarizing are complex phenomena and, as it seems, they have different forms. Solidarity, to be precise, is an objective correlate of the act of solidarizing. If we consider solidarizing en bloc, and we refer to the use of ordinary language, we can treat it as, say, agreement, unanimity, acceptance, supporting each other, or co-responsibility for something or someone. Just as solidarizing can have different forms, so also solidarity is ambiguous. It seems, however, that at the beginning of this study solidarity can be described - again, by referring to the use of ordinary language - as a certain (a) relation between (b) a subject, a person or an agent and (c) something (e.g. a value or an opinion) or (d) someone. If one solidarizes with something, one can call this form of solidarity the object-directed solidarity, if one solidarizes with someone, the subject-directed solidarity. What is even more important, solidarizing can have both (e) positive or (f) negative character. In the latter case, one is faced with de-solidarization which means a rejection or a protest. If one de-solidarizes with a value, he or she rejects or does not accept the value. In spite of this, solidarity can be regarded either as (g) egoic solidarity if one speaks of a single subject, a person, or an agent, or as (h) intersubjective solidarity if the phenomenon concerns two or more subjects. An example of egoic solidarity is a spontaneous acceptance of a value. In turn, an example of intersubjective solidarity is if one solidarizes with a friend or with a group of people, or a solidarity of the group with a value or an opinion. 
From a phenomenological point of view, all these distinctions have to be classified as rooted in the natural attitude. They precede a philosophical analysis, and as such they require further elaboration. Of course, solidarity as an idea has its history which goes back to, e.g. Durkheim, Weber and Marx (Stjernø 2005), and more importantly, it resonated in the phenomenological movement in the thought of, e.g. Scheler, or Wojtyła (Pope John Paul II) (Gubser 2014), however, my concern here is not the question of historical interconnections of solidarity and phenomenology. Rather, what I aim at is a systematic approach to solidarity. In this article, namely, I will describe intersubjective solidarity as an example of a social phenomenon, and I will argue that this form of solidarity aims at establishing relations by grouping subjects in spontaneous or organized groups. In a word, my purpose is a phenomenology of solidarity understood as a process of constituting groups, where phenomenology is comprehended as a descriptive analysis of meaningful phenomena, and solidarity - I claim - is a kind of phenomenon. The presented analysis, then, can be regarded as a part of social phenomenology. In this context, however, one can formulate a crucial charge: how can phenomenology account for social phenomena at all? After all - goes a typical argumentation (e.g. Theunissen 1977: 246) - phenomenology is a kind of 'neo-Cartesianism' (Husserl 1960: 1) which is focused on subjective experiences only. Moreover, a methodological tool of reduction requires a 'suspension' or even 'rejection' of the intersubjective context. In a word, phenomenology seems to fail in describing social phenomena in general, and therefore - solidarity in particular. In contrast to this popular interpretation, however, it is worth to note that for Husserl (1989: 178) solipsism is an 'illusion' (Schein) in phenomenology, as the claim that only the ego exists is meaningless (Husserl 1958: 496). Recent intense studies on Husserl (e.g. Mensch 1988; Zahavi 1996, 2014; Ratcliffe 2012; Jardine, Szanto 2017) support Husserl's position and justify the claim that the problem of solipsism is indeed absent in phenomenology; even more, since Husserl formulated a complex theory of intersubjectivity and he shows that, in the end, there is no subjectivity without intersubjectivity. If this is the case, how phenomenology can contribute to the analysis of solidarity?

In the first place, it has to be noted that solidarity is a social phenomenon, and as such it presents itself as meaningful. My thesis with this regard is that its meaning is constituted in intersubjectively co-constituting joint actions directed towards aims and values. To show this, I will refer to genetic phenomenology since - as I will argue - a group is not a static structure, but rather it is constituted in a dynamic process, which establishes a new way of experiencing the world as 'our' world. First, however, I will critically examine the idea of solidarity as presented by Ingarden and Tischner. As it is well known, Ingarden was a student of Husserl in Göttingen. Tischner, in turn, was a student of Ingarden, and a founder of the original theory of solidarity. ${ }^{1}$ In any case, both philosophers refer to egoic solidarity, and Tischner later tries to reinterpret it as the intersubjective one. Nonetheless, as I will try to show in this study, phenomenology that begins with the egoic and immanent dimension of solidarity cannot adequately reveal how a group becomes constituted. I will define the problem of a possible shift from the subjective solidarity to the intersubjective one as the bridge problem. In the second part of the article I will sketch an alternative approach to solidarity which - by referring to the methods of static and genetic analyses - asks about the structures of the act of solidarization. I will refer mainly here to Husserl's texts, and I will try to show the structure of solidarization as an act, which constitutes groups oriented towards a realization of a certain aim. In the last part of the paper, I will describe solidarity as a way of comprehending the world as the common world for which one is co-responsible.

\footnotetext{
1 More on Tischner, and an outline of his philosophical position, can be found in Domagala 2002.
} 


\section{FROM EGOIC SOLIDARIZATION TO SOCIAL SOLIDARIZATION: THE BRIDGE PROBLEM}

The practical philosophy of Ingarden - which defines a conceptual framework for his analysis of the phenomenon of egoic solidarity (the term of Ingarden) - binds the results from ontology (the existential status of values), theory of knowledge (a discussion with relativism), and from philosophical anthropology (understanding of a human being as a relatively isolated system). ${ }^{2}$ To define his philosophy in a broad way, one can say that Ingarden (1989: 337) does not resolve the problem of the existence of values, and he claims that values are instantiated in the world by the subject who is responsible for its realization. At the basis of the realization one finds, then, an axiological experience which, as any experience, has the intentional structure of subject-object. And so, (a) from the objective point of view, values 'demand' a realization, because a value 'should' exist (Węgrzecki 1995b: 155-156). In turn, (b) from a subjective point of view, Ingarden speaks of experiencing values in the form of emotional reaction (Węgrzecki 1995a: 165). Ingarden (1989: 217) describes the phenomenon of solidarization ${ }^{3}$ and de-solidarization in the context of subjective reaction to values as an emotional reaction. He writes about 'spontaneous', 'clearly unconscious', and 'unreasonable' relation to what is actually lived through, and he states that this relation has a character of 'involuntary' and 'emotional' feeling of acceptance or refusal (Ingarden 1989: 218). Solidarization or de-solidarization with certain emotions shows that the reaction of the moral subject is good or bad, and for this reason he or she can be aware of responsibility for his or her actions.

In spite of the question of ontological foundations of responsibility (Ingarden 1970), it is evident that for Ingarden egoic solidarity is defined as an emotional reaction to values, and this reaction makes the subject responsible for certain actions. In contrast, if responsibility does not have a mere egoic character, but rather also concerns a society, it has the form of co-responsibility for what is happening in the society. Ingarden (1989: 247) describes this aspect by claiming that one is responsible for something, although he or she does not do this. This form of responsibility is characteristic of the intersubjective solidarity. Intersubjective solidarity introduces two important differences in relation to the egoic one: (a) it is a relation to the group or another subject; (b) it is a correlate of co-responsibility that limits freedom of the moral subject (in Ingarden's words: 'I do not do this'). Ingarden's analysis does not stop here. He asks about the relation between egoic and intersubjective solidarity. He tries to show that if solidarity with someone follows from my personal interests, and if it does not follow from the feeling of my responsibilities for the group, such action then does not have any moral value (Ingarden 1989: 321). If this is the case, Ingarden in fact reduces social solidarity to egoic solidarity, since it is grounded in subjective feelings. Moreover, it is questionable if one is able to phenomenologically consider the basis from which solidarity follows. From the fact that I feel responsible for something, it does not follow that I am co-responsible for anything.

Węgrzecki (2007: 85), while drawing the basic difference between Ingarden and Tischner, his student from Cracow, claims that whereas, for the former, egoic consciousness is primordial, for the latter, the ego is constituted within the act of solidarization. By claiming this, however, Tischner takes over Ingarden's understanding of egoic solidarization, and he describes solidarization as an immanent reaction of the subject to values. Tischner (2006: 220-228) claims that egoic solidarization plays a crucial role in the process of establishing the axiological self, i.e.

\footnotetext{
2 An overview of Ingarden's ethics was formulated by Gołaszewska (1976).

3 I use the term 'solidarization' here, as in the entire article, in the sense of Ingarden and Tischner as 'an act of solidarization'.
} 
the core of the subject. Nonetheless, Tischner's account of solidarization leads toward similar problems as Ingarden's theory: it does not account for intersubjective solidarity. In his later concept of the ethics of solidarity, Tischner seems to overcome the limits of the early theory of the axiological self. After all, Tischner claims that solidarity is a social phenomenon since - as he argues - '[s]olidarity is a solidarity with people and for people' (Tischner 2007: 40). As such, it is realized in the face of someone's injustice. This means, however, that solidarity is first and foremost a moral phenomenon. How, then, according to Tischner, does social solidarity constitute itself? Tischner states that solidarity is the case of conscience, which is understood in a natural ethical sense, and is experienced as a spontaneous and infallible call to action in a certain way. The action is undertaken in the social context. Tischner's connection of solidarity with conscience is, then, justified as an attempt of describing the way how a community or a group is constituted. Even if one can lose his or her conscience, as Tischner states, conscience justifies and creates a community. After all, the natural ethical sense is experienced as the 'internal voice' which is described by Tischner as acceptance or rejection of a certain value or group of values which, in turn, establishes a relation between both subjects. As Dobrosław Kot explains, 'Tischner wants solidarity to be born in the deepest parts of subjectivity. It cannot be forced, it cannot be imposed. It must be a personal answer of man to the voice of the one who calls' (Kot 2007: 99-100). Here, however, the bridge problem arises: Tischner asks what is more fundamental: '[s]olidarity establishes specific interpersonal bonds; a man binds himself to another man in order to protect the one who needs care. I am with you, you are with me, we are together - for him. What is first here? Are 'we' first, or is 'for him' first?' (Tischner 2007: 41). According to Tischner, community of solidarity is characterized by the primacy of 'for him', and 'us' comes later. So, first there is my egoic experience of the voice of conscience. It is from this basis that community can arise.

It seems, however, that Tischner's solution is questionable for at least three reasons. First, it is not clear what Tischner understands in this context by 'the beginning' of experiencing, and 'after'. Secondly, Tischner's description presupposes community, and it does not explain its possibility. Finally, it leads toward a vicious circle. And so, Tischner can refer here to temporal, ontological, logical or transcendental orders while speaking of what comes at the beginning of solidarity. If one considers the context of Tischner's text, it seems that he refers to the temporal order. If so, it is unclear how 'here arises community', i.e. how it is possible to shift the focus from 'for him' to 'us.' The bridge problem concerns here the moment when someone individually experiences his or her reaction, and another moment when the community is already given. For this reason, as it seems, community is presupposed, but not explained. Moreover, if solidarity equals solidarity of consciences, community is presupposed at the beginning, and is only reestablished in the second step of Tischner's argumentation. Here, then, one notices a vicious circle: community constitutes itself, because the subject has a certain experience, but that experience is possible, because the subject is a member of the community.

\section{ELEMENTS OF THE ACT OF SOLIDARIZATION AS A COMPLEX ACT}

Both, Ingarden and Tischner, while asking about egoic and intersubjective solidarity, are unable to solve the bridge problem. In this part of the article, I try to sketch out an alternative way to get rid of the problem. It seems that Ingarden and Tischner make a false supposition that to follow intersubjective solidarity from the egoic one is necessary at all for understanding what solidarity as a social phenomenon is. In turn, I want to show that Tischner is too hasty in differentiating 'for him' and 'we', and that he does not understand that both terms actually 
refer to one experience. What solidarization introduces is a way of how the subjects experience the world; again, there is no different experience. For this reason, in spite of the question about subjective conditions of solidarity as a social phenomenon, I want to ask here about the structure and elements of the act of solidarization. To do so, I will refer mainly to Husserl's theory.

The act of solidarization is a complex act, which means that it is founded on different acts and can be described in a mereological vocabulary of wholes and parts. ${ }^{4}$ This description concerns the whole of the act of solidarization which binds cognitive, volitional and affective acts. As it seems, however, the cognitive aspect of the act is marginal, since while solidarizing the subject first of all wants to undertake certain actions, and he or she feels certain emotions. The volitional act limits the actions of the agent with regards to the aim, which is realized by the group. This means that a community can realize an aim, which the subject does not want to realize. This is still the case, even though the subject is co-responsible for the others and this means that he or she has to suspend his or her personal preferences in favour of the community. As a social act, solidarization seems to have a dual object. The first object is another subject, or the group of subjects. The second objects are values, concerning which, the subject solidarizes with other subjects. Precisely, because of the reference to values, the act of solidarity is a complex act, which incorporates also an emotional act that fulfils its intention. ${ }^{5}$ The volitional act, in contrast, concerns joint actions. Without the volitional act, the act of solidarity seems to be equivalent with the act of empathy (that is, it lacks the component of action), which founds more complex forms and dimensions of social acts.

If one considers a subjective side of the act of solidarization, the question of how to understand the subject arises. This question seems to be of primal importance if one keeps in mind Husserl's (1973: 165-184, 192-204) proposal of understanding it as a 'common spirit' (Gemeingeist). This description - as Alfred Schutz (1957) seems to prescribe - can suggest that solidarity as a social phenomenon has its own subject which is different than individual subjects, and that the 'common' subject has its own properties such as beliefs, actions or emotions. In contrast to this view, however, the description - as Thomas Szanto (2016: 165) shows - does not presuppose the existence of special phenomenal properties of 'collective consciousness.' Rather, Husserl refers here to the intersubjective character of the subject. After all, for Husserl, subjectivity constitutes itself in a community, and for this reason it is related to another subject, which means that subjectivity has the form of ego-alteri. ${ }^{6}$ Therefore, in contrast to Tischner, the subject is not the member of the community which constitutes itself in the acts of solidarity because he or she has certain subjective experiences. Rather, the act of solidarization changes the way of experiencing the world, namely one experiences the world as a correlate of the group or the community. How, then, does the group constitute itself in the act of solidarization?

${ }^{4}$ On Husserl's understanding of a complex act, see Husserl 2001: 4-7, and on his theory of parts and wholes, see Sokolowski 1968.

5 "Der intellektiven Erfüllung läuft parallel die emotionale. Das Werten ist nicht nur richtig, sondern vollkommen begründet, und diese Begründung besagt nicht Begründung durch das Denken, sondern Gemütsbegründung" (Husserl 1988: 241).

6 "Die Gemeinschaftssubjektivität ist eine vielköpfige Subjektivität, Form des ego-alteri. Jedes vergemeinschaftete ego hat nicht nur sein Bewusstsein, sondern seines als in die Anderen hineinschauendes und sich mit den Anderen zu einem universalen Bewusstseinszusammenhang mit vielköpfiger Subjektivität verbindend, aber freilich sich ins Unbestimmte verlierend" (Husserl 1973: 218). 


\section{A GENETIC ACCOUNT OF SOLIDARITY: ON CONSTITUTING GROUPS}

Both Eric Chelstrom (2013) and Emanuele Caminada (2016) emphasize that genetic phenomenology allows for Husserl to understand social phenomena more adequately. It is possible for two reasons: (a) genetic phenomenology takes into account a description of experience as horizontal what means that the subject is always already embedded in social, cultural and historical contexts (Chelstrom 2013: 109); (b) it does not ask about structures of joint experiences, but rather about the process of solidarization (Caminada 2016: 290). It was mentioned already that the act of solidarization constitutes the group, which organizes its actions as oriented toward certain aims and values. What does it mean, however, that the group constitutes itself in the act of solidarization?

To begin with, one can ask the question: What does it mean at all to ask here about the genesis of the group? Of course, the question does not concern a causal chain which results in establishing the group. Rather, I am asking about the passive-affective experiences as the process of sense constitution. As suggested earlier, the group which constitutes itself in the act of solidarization is a complex structure that builds a personality of higher order. Regarding Husserl's social philosophy - as Szanto (2016: 150-151) rightly shows - one can indicate four forms of social consciousness: (a) empathic consciousness (a spontaneous experience of consciousness of other subjects); (b) synthetic consciousness of the world (experience of the world as the same for different subjects); (c) social consciousness (a sense of being a member of a certain group, say, a family or a social class); finally, (d) consciousness of higher order sui generis, which realizes itself in single actions. The act of solidarization seems to be the act of higher order what leads toward the question about passive-affective experiences of the world. To ask about the genesis of solidarity, then, means to ask how solidarity determines experience of the world. However, if one speaks at the passive-affective level, a genetic account of solidarity has to accept correlative understanding of experience, i.e. the communal world is experienced as already constituted by the community and communalized subjects. Therefore, there is no individual person without another individual and without a community of persons. Solidarity, then, is a form of social process, which founds subjectivity on both individual and intersubjective levels. Nonetheless, let me emphasize once again, it happens on the passive and affective level. This subjectivity is defined as co-responsible for a realization of certain values in individual actions. Co-responsibility is connected with the passive-affective embeddedness of solidarity: although the subject actively does not want to do something, he or she has to suspend his or her personal preferences and he or she has to act for the common good. Husserl calls such a community - a community of will (Willensgemeinschaft), and he analyses the phenomenon of joint actions. Let me look closer at Husserl's example.

And so, Husserl describes different complex cases of joint actions and commitments. At the beginning, he writes, 'I will satisfy your desire if you would satisfy mine, I will do something good for you, if you would work in my favor,' and he adds: 'Furthermore: We both want something to happen, we "jointly" ("gemeinsam") take a decision, I do my respective part, you do yours' (Husserl 1973: 170). The situation is more complex, since a community is not a separate subject different than its members. In turn, the aim is common in this sense that agents want its realization as a joint aim. Husserl describes this in the following way: ' $S_{1}$ and $S_{2}$ want the same $G$, but not each of them separately, for their own sake, but $S_{1}$ wants $\mathrm{G}$ as something that is equally wanted by $S_{2}$, the will of $S_{2}$ is the part of what is wanted by $S_{1}$ and conversely' (Husserl 1973: 170). In his comment to this fragment of Husserl's text, Szanto emphasizes that 'by the very intention through which one subject functionally enters, or is realized in, the intentional content of another subject as joint "means" to attain a shared goal' (Szanto 2016: 159). What is important here is that community is constituted by aim-oriented actions, and not by a separate subject. Therefore, 
what is constituted here is a shift in comprehending the aim. Now, namely, the subject aims toward a joint aim, what means the following: the subjective perspective becomes the intersubjective one. At the level of language, this crucial shift is marked by a shift, for instance, of the phrase: 'I want G' to 'we want G. The group, then, constitutes itself in joint actions which, in turn, are constituted in the act of solidarization as a normative act of co-responsibility. Solidarity, to phrase it differently, is realized in the very processes of constituting a community.

\section{CONCLUSIONS}

The main aim of this article was an attempt to analyse solidarity phenomenologically as a social phenomenon. By differentiation - following Ingarden, and Tischner - of the egoic solidarization and the intersubjective one, I tried to show that acts of solidarization constitute groups, and that the acts determine experience of the world in modi 'we.' Given that the phenomenon of solidarity is analysed mainly in the context of political philosophy, and personalism (e.g. Doran 1996; Taylor 2007), an attempt in describing solidarity as a social phenomenon in the context of constituting groups seems to be an original contribution of the presented analysis. This general description, of course, does not reject that also the intersubjective solidarity has different forms and levels: from, for instance, a solidarization with a friend to a solidarization of whole social classes and communities. What is common in these different forms of solidarity is an attempt to build a higher-order subjectivity. In solidarity, namely, a subject constitutes a new sense of experience. It is, then, a goal-oriented process in which one overcomes a subjective point of view and his- or her-own preferences by accepting his or her co-responsibility for the world. For this reason, one can conclude that the act of solidarization is essentially the act of transcending. This description, however, is still partial since every act seems to be the act of transcending, namely every act is characterized by intentionality. What, then, makes the act of solidarization different than other acts?

To answer the question I have discussed critically theoretical positions of Ingarden and Tischner; they both were unable to resolve the bridge problem. The problem concerns an unjustified attempt to ground intersubjective solidarity in the egoic one. Of course, the presented analyses can be pushed forward by, e.g. a deeper study on how Patočka (1996: 135-137) formulated his theory of the solidarity of the shaken. Nonetheless, my aim here was not a reconstruction of the problem of solidarity in the tradition of the phenomenological movement. Rather, I wanted to describe solidarity as a complex act which binds cognitive, volitional and affective elements. This alternative way rejects the bridge problem as illusionary since - as I tried to show - solidarity is an autonomous phenomenon, which is co-constituted on a social dimension. Therefore, the result that follows from the presented analyses is that the essence of solidarity as a social phenomenon is its intersubjectivity that is realized in joint actions. I do not claim, of course, that every act of a joint action should be understood as solidarization. Such thesis is simply unjustified. What characterizes the act of solidarization is its normative aspect which results in experiencing co-responsibility for other members of a community. This act constitutes a higher-order subjectivity what means that a subject experiences the world in modi 'we'.

Received 21 May 2018

Accepted 15 June 2018

\section{References}

1. Domagala, E. 2003. "Józef Tischner's Philosophy of the Human Being”, in Phenomenology World-Wide: Foundation - Expanding Dynamics - Life-Engagements. A Guide for Research and Study, ed. A.-T. Tymieniecka. Dordrecht: Kluwer Academic Publishers, 494-497. 
2. Doran, K. 1996. Solidarity: A Synthesis of Personalism and Communalism in the Thought of Karol Wojtyla/ Pope John Paul II. New York: Peter Lang.

3. Gołaszewska, M. 1976. "Roman Ingarden's Moral Philosophy”, Analecta Husserliana 4: 73-103.

4. Gubser, M. 2014. The Far Reaches. Phenomenology, Ethics, and Social Renewal in Central Europe. Stanford: Stanford University Press.

5. Husserl, E. 1958. Erste Philosophie (1923/24). Zweiter Teil. Theorie der phänomenologischen Reduktion, ed. R. Boehm. Den Haag: Martinus Nijhoff.

6. Husserl, E. 1960. Cartesian Meditations. An Introduction to Phenomenology. Transl. by D. Cairns. The Hague, Boston, London: Martinus Nijhoff.

7. Husserl, E. 1973. Zur Phänomenologie der Intersubjektivität. Texte aus dem Nachlass. Zweiter Teil: 19211928, ed. I. Kern. Den Haag: Martinus Nijhoff.

8. Husserl, E. 1988. Vorlesungen über Ethik und Wertlehre. 1908-1914, ed. U. Melle. Dordrecht, Boston, London: Kluwer Academic Publishers.

9. Husserl, E. 1989. Aufsätze und Vorträge (1922-1937), eds. T. Nenon and H. R. Sepp. Dordrecht, Boston, London: Kluwer Academic Publishers.

10. Husserl, E. 2001. Logical Investigations. Vol. 2. Transl. by J. N. Findlay. London: Routledge.

11. Ingarden, R. 1970. Über die Verantwortung. Ihre ontische Fundamente. Stuttgart: Reclam.

12. Ingarden, R. 1989. Wykłady z etyki. Warsaw: Państwowe Wydawnictwo Naukowe.

13. Jardine, J. A.; Szanto, T. 2017. "Empathy in the Phenomenological Tradition", in Routledge Handbook of Philosophy of Emathy, ed. H. L. Maibom. London: Routledge, 86-97.

14. Kot, D. 2007. "Solidarity Without Solidarity", Thinking in Values 1: 96-106.

15. Mensch, J. R. 1988. Intersubjectivity and Transcendental Idealism. New York: SUNY Press.

16. Patočka, J. 1996. Heretical Essays in the Philosophy of History. Transl. by E. Kohák. Chicago, La Salle: Open Court.

17. Ratcliffe, M. 2012. "Phenomenology as a Form of Empathy", Inquiry. An Interdisciplinary Journal of Philosophy 55(5): 473-495.

18. Schutz, A. 1957. "Das Problem der transzendentalen Intersubjektivität bei Husserl", Philosophische Rundschau 5: 81-107.

19. Sokolowski, R. 1968. "The Logic of Parts and Wholes in Husserl's Investigations", Philosophy and Phenomenological Research 28(4): 537-553.

20. Stjernø, S. 2005. Solidarity in Europe. The History of an Idea. Cambridge: Cambridge University Press.

21. Szanto, T. 2016. "Husserl on Collective Intentionality", in The Phenomenological Approach to Social Reality, eds. A. Salice and H. B. Schmid. Dordrecht: Springer, 145-172.

22. Taylor, C. 2007. "Several Reflections on the Theme of Solidarity", Thinking in Values 1: 68-77.

23. Theunissen, M. 1977. Der Andere. Studien zur Sozialontologie der Gegenwart. Berlin, New York: Walter de Gruyter.

24. Tischner, J. 2006. "Fenomenologia świadomości egotycznej”, in Studia z filozofi świadomości, ed. J. Tischner. Cracow: Instytut Myśli Józefa Tischnera, 129-422.

25. Tischner, J. 2007. "The Ethics of Solidarity", Thinking in Values 1: 37-51.

26. Węgrzecki, A. 1995a. "O doświadczeniu aksjologicznym”, in W kręgu filozofii Romana Ingardena. Materiały z konferencji naukowej Kraków 1985, eds. W. Stróżewski and A. Węgrzecki. Warsaw, Cracow: Wydawnictwo Naukowe PWN, 161-166.

27. Węgrzecki, A. 1995b. "Podmiotowość i wartości", in Roman Ingarden a filozofia naszego czasu, ed. A. Węgrzecki. Cracow: Polskie Towarzystwo Filozoficzne, 148-160.

28. Węgrzecki, A. 2007. "Tischner i Ingarden”, Kwartalnik Filozoficzny 35(1): 77-88.

29. Zahavi, D. 1996. Husserl und die transzendentale Intersubjektivität. Eine Antwort auf die sprachpragmatische Kritik. Dordrecht, Boston, London: Kluwer Academic Publishers.

30. Zahavi, D. 2014. Self and Other: Exploring Subjectivity, Empathy, and Shame. Oxford: Oxford University Press. 
WITOLD PŁOTKA

\title{
Solidarumo fenomenologijos metmenys: anapus tilto problemos
}

\begin{abstract}
Santrauka
Pagrindinis straipsnio tikslas - pristatyti pagrindinius elementus, problemas ir preliminarius sprendimus, susijusius su solidarumo fenomenologija. Straipsnis sudarytas iš trijų dalių. Pirmojoje dalyje autorius apibréžia tilto problemą kaip bandymą susieti subjektyvų ir intersubjektyvų konstitucijos klodus. Be to, jis parodo, kad nei Ingardenas, nei Tischneris šios problemos išspręsti negali. Antrojoje dalyje pristatomas solidarizavimosi aktas kaip sudètinis aktas, siejantis pažinimo, valios ir jausmų dimensijas. Galiausiai autorius pateikia alternatyvų požiūrị ị solidarumo fenomenologiją. Šis suvokimas nukreipia anapus tilto problemos, būtent Husserlio grupių konstitucijos bendrų veiksmų teorijos.
\end{abstract}

Raktažodžiai: intersubjektyvumas, solidarizavimasis, bendri veiksmai, grupių konstitucija, Ingardenas, Tischneris, Husserlis 